○宮田耕志 1）、大森孝一 2)、庄司和彦 2)、児㟃久剛 2）、平野滋 2)
1）長浜赤十字病院耳咽喉科
2) 京都大学医学部耳咽搌科

(はじめに)

現在、難聴者の語音聴取能の評価や、補聴器の装用効果判定には、テープやCDが広く使 用されている。テープやCDでは、1リストの検查音が連続して被検者に呈示され、1リス ト全体の正答率という定量的な評価は可能であるが、検查音ひとつひとつを個別にとりだ すことが困難であるため、検査音別の認知についての評価は容易ではない。そこで、今回 我々は、検査音の選択と呈示する音圧が自由に設定でき、呈示された検查音に対する被検 者の答えの正誤をそのつど判定できる対話式語音聴力検查法を考案した。これにより、難 聴者の語音聴取能をより詳細に検討することが可能となった。

(方法)

1. 検查音の作成方法

プロのアナウンサーが防音室で発声した音声を、マイクロフォンよりサンプリング周波 数 48kHzにてDATレコーダに録音した。これをコンピュータ上で各音の最大音圧を一定と したのち、サンプリング周波数 $44.1 \mathrm{kHz}$ のサンドファイルに変換し、ノート型パーソナル コンピュータに保存した。検查音ひとつひとつを音声ファイルとし、画面上で選択してダ ブルクリックするだけで検查音が呈示される。

2. 検查音の選択

図 1 は、現在使用している検查音である。単音として、子音弁別能をみるために後続母 音を/a/と一定にした13の子音・母音音節と、5 音を用いている。また、日常の会話聴 取能力を反映させるものとして、日本語の有意味短文を検查音として使用しており、5文、 20文節よりなるリストを用いている。困1にあるのは、その一例である。話速についても 評価できるよう、普通の話速のリストと、ゆっくりした話速（時間あたりの単音数が普通 の話速の0.7倍）のリストを用意した。検查結果の評価は、全文節中正解した文節の割合 (\%) で行っている。

\title{
3. 検查方法
}

因 2 右のように、コンピュータを補聴効果測定装置の外部入力に接続し、スピーカから 検查音を呈示することで、防音室での補聴器装用効果判定や、人工内耳術後患者の語音聴 取能の評価が行える。また、四 2 左のように、オージオメータに接続し、ヘッドホンから 検查音を呈示すれば、従来の語音検查と同じょうに片耳ごとの語音聴取能を測定すること もできる。いずれにしても、コンピュータ上で検查音を自由に選択して、補聴効果测定装 置あるいはオージオメータで音圧を自由に変えて検査音を呈示できる。呈示された各検査 音に対し、被検者は呈示ことに答え、その正誤はそのつど判定されることになり、従来の テープやCDでの検查音の連続呈示では困難であった対話式の（インタラクティブな）検查 が可能となった。

(症例)

図 3 に実際に検查を行った症例の検査結果を示す。症例は、57歳、女性で、人工内耳埋 
め込み術後20日目での検查結果である。榆查音の呈示は防音室にて90dBで行った。単音の 聞き取り検查の結果は、母音では/0/が認知できず、子音・母音音節も13のうち12が認知 不能であった。しかし、短文の聞き取りは、普通の話速の短文では $60 \%$ 認知できており、 さらに、話速のゆっくりした文では $80 \%$ 認知可能であり、単音と文章では聴取能にかなり 大きな差があることがわかった。

このように、今回のシステムを用いると、従来の検查では困難であった人工内耳術後患 者の語音聴取能や補聴器装用効果判定など難聴者の語音聴取能をより詳細に検討すること が可能となり、対話式語音聴力検查法は有用なシステムであると思われた。

（因 1 : 使用している検查音）

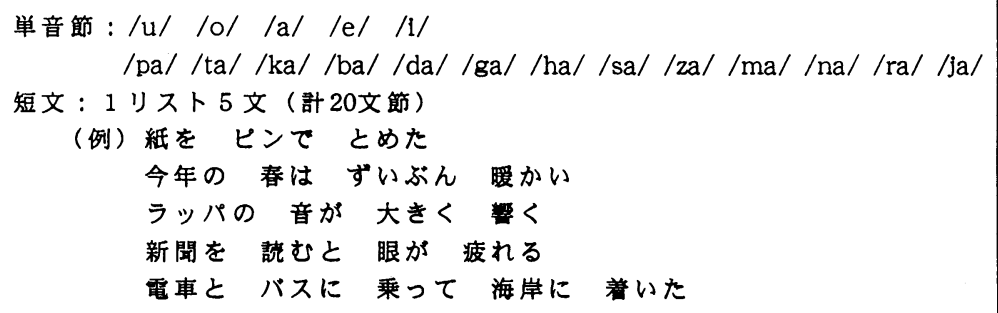

（図2：今回考案したシステム）

\section{片耳ことの酛音机取能测定}

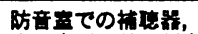

人工内耳の奻果弹定

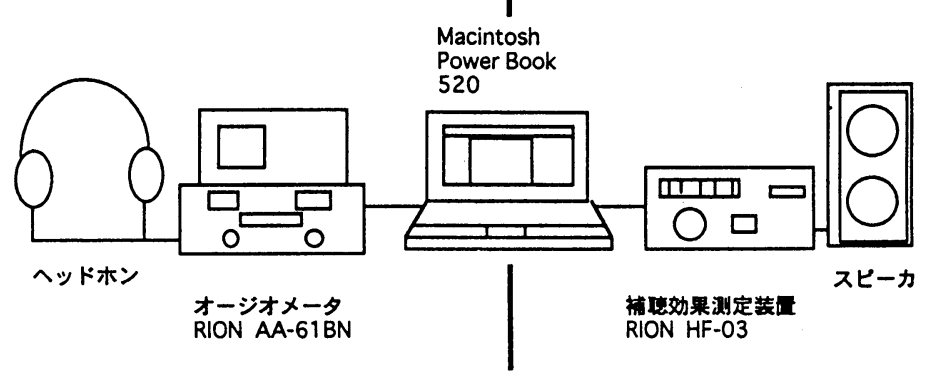

（図 3：人工内耳術後患者の検查結果）

単音節 : $/ \mathrm{u} / \mathrm{d} / \mathrm{/} / \mathrm{a} / \mathrm{e} / \mathrm{d} /$

$90 \quad 90 \quad 90 \quad 90$

$/ \mathrm{pa} / \mathrm{ta} / \mathrm{ka} / / \mathrm{ba} / \mathrm{da} / / \mathrm{ga} / / \mathrm{ha} / / \mathrm{sa} / \mathrm{za} / / \mathrm{ma} / / \mathrm{na} / / \mathrm{ra} / / \mathrm{ja} /$

90

(下段の数値は認知可能であった呈示音圧（dB）で、数値の記載のないのは認知不能であったことを示す）

短文：普通の話速：60\%（12/20文節）認知可能

ゆっくりとした話速：80\%（16/20文節）認知可能 